\title{
Some Observations of the Azores Current and the North Equatorial Current
}

\author{
Lothar Stramma and Thomas J. Müller
}

Institut für Meereskunde, Universität Kiel, Kiel, Federal Republic of Germany

\begin{abstract}
The regions containing the two zonal currents of the subtropical gyre in the eastern North Atlantic, the Azores Current and the North Equatorial Current (NEC), have quite different physical characteristics. Associated with the Azores Current are strong horizontal thermohaline gradients that can be located easily both at the surface and at depth with temperature data alone, thus making satellite IR imagery and expendable bathythermograph profiles suitable for observing it. During winter, the surface expression of the Azores Current is often found to the north of the strongest subsurface gradients. In contrast to the Azores Current and to the central water mass boundary just to the south, the NEC has relatıvely weak horizontal temperature and salinity gradients, requiring density information in order to identify it. There is no clear surface manifestation found with the NEC. Common to both currents, though, is that each transports $O(8 \mathrm{~Sv})$ in the upper $800 \mathrm{~m}$ of the ocean near $27^{\circ} \mathrm{W}$, with the largest velocities being in the upper $400 \mathrm{~m}$.
\end{abstract}

\section{INTRODUCTION}

The current cores in the northwest Atlantic, particularly the Gulf Stream, are recognized as being well-defined boundaries between distinct water masses. Owing to the strong horizontal temperature gradients at the surface, the Gulf Stream is easily located in satellite infrared (IR) images [Cornillon, 1986], as has been verified with in situ observations [Cornillon and Watts, 1987]. Fiedler [1988] reported that some aspects of subsurface structure within limited regions of the California Current have surface manifestations potentially detectable by satellite sensors. However, as compared with the flows along the western boundary, the currents in the mid-Atlantic have relatively weak signals. Also, as opposed to the western boundary currents, little information exists with regard to their structures. In this study we present spring and fall sections across the two zonal flows contained in the North Atlantic subtropical gyre: the Azores Current and the North Equatorial Current (NEC).

The Azores Current appears to be related to a thermohaline front [Gould, 1985; Käse et al., 1986] and is in close proximity to a deep chlorophyll maximum [Fasham et al., 1985]. The structure of the Azores Current can be tilted away from the vertical by a substantial amount, at least within the upper portion of the water column. Käse and Siedler [1982] and Siedler et al. [1985] determined the location of the subtropical front associated with the Azores Current on the basis of the maximum horizontal temperature gradients at the surface, which for them was north of $35^{\circ} \mathrm{N}$. But by using conductivitytemperature-depth (CTD) data from the same cruises, Stramma [1984] found the greatest transport rates as being south of $35^{\circ} \mathrm{N}$. Such shifts are studied in more detail here. We also discuss differences between the large-scale thermohaline structures of the Azores Current and the NEC, whether these currents are associated with clear temperature gradients at the surface, and which simple oceanographic measurements are required for investigating these currents.

In March and April 1982, during cruise M60 of R/V Meteor, a pair of long meridional CTD sections were made along $27^{\circ} \mathrm{W}$ and $33^{\circ} \mathrm{W}$. To investigate the NEC, we use eight

Copyright 1989 by the American Geophysical Union.

Paper number $88 \mathrm{JC} 04192$.

$0148-0227 / 89 / 88 \mathrm{JC}-04192 \$ 05.00$
CTD stations along $27^{\circ} \mathrm{W}$ between $26^{\circ} \mathrm{N}$ and $15^{\circ} \mathrm{N}$ (Figure 1). For the Azores Current we use stations along $33^{\circ} \mathrm{W}$, together with those on a diagonal line to the Azores, comprising a total of seven CTD stations. The line of stations made by $R / V$ Meteor (cruise 60) along $27^{\circ} \mathrm{W}$ extends farther north and spanned the Azores Current, but for our purposes the station spacing was unacceptably large. As an alternative, we use eight CTD stations of R/V Poseidon cruise P124 in November 1985 along $26^{\circ} 30^{\prime} \mathrm{W}$ between $37^{\circ} \mathrm{N}$ and $31^{\circ} 55^{\prime} \mathrm{N}$ (Figure 1). Finally, as an additional section across the NEC, we use nine CTD stations along $27^{\circ} \mathrm{W}$ between $16^{\circ} \mathrm{N}$ and $25^{\circ} \mathrm{N}$ taken in November 1986 during cruise M4 of the new R/V Meteor. We also present surface temperatures that were continuously measured at the ships' water intakes. Although there are uncertain systematic errors in such measurements, of the order of $0.1^{\circ} \mathrm{C}$ or less, the relative changes in temperature are well represented.

\section{Observations}

We first address the question as to whether we can identify and describe the Azores Current and the NEC by surface or near-surface data alone, such as satellite infrared images, surface temperature, and salinity from ship intakes, or from expendable bathythermograph (XBT) sections. Shown in Figure 2 are the temperature and salinity distributions of all the sections in Figure 1 projected onto longitude. The strongest horizontal temperature and salinity gradients in spring (M60) as well as in fall (P124) appear to be between $33^{\circ} \mathrm{N}$ and $36^{\circ} \mathrm{N}$, in the region of the Azores Current, from the surface down to $600 \mathrm{~m}$ to $800 \mathrm{~m}$. Inspection of the corresponding relationship (not shown) between potential temperature $\theta$ and salinity $S$ reveals only very little change within the North Atlantic Central Water, or NACW (less than 0.02 in practical salinity at fixed temperature), across this front.

The situation differs at the southern boundary of the gyre. Here, between $17^{\circ} \mathrm{N}$ and $23^{\circ} \mathrm{N}$, the gradients in temperature and salinity are weaker and are capped by the mixed surface layer and subtropical salinity maximum [Bauer and Siedler, 1988]. Furthermore, these gradients appear twice, first between $17^{\circ} \mathrm{N}$ and $19^{\circ} \mathrm{N}$ and then between $21^{\circ} \mathrm{N}$ and $23^{\circ} \mathrm{N}$. Again, inspection of the $\theta-S$ relationship shows almost no change in the central water mass characteristics across the northern part of the frontal zone which carries the NEC, as will be shown below. South of $21^{\circ} \mathrm{N}$ the transition zone be- 


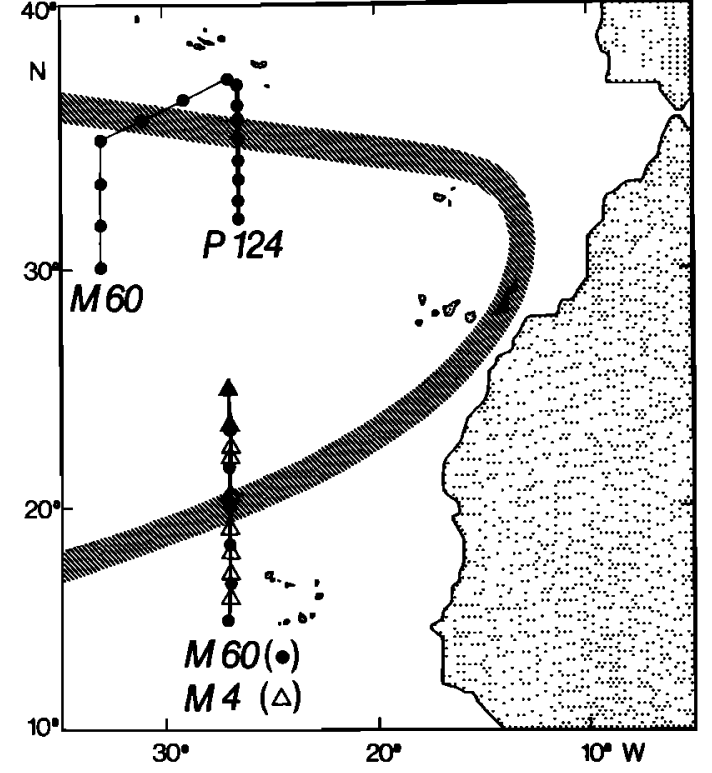

Fig. 1. Locations of CTD stations by R/V Meteor cruise 60, (denoted as M60) in March and April 1982, by R/V Poseidon cruise 124 (denoted as P124) in mid-November 1985 , and by the new $R / V$ Meteor cruise number 4 (denoted as M4) in November 1986. Also shown is a schematic presentation of the subtropical gyre in summer in the upper $200 \mathrm{~m}$ of the ocean [Stramma and Siedler, 1988].

tween the central waters of the North and South Atlantic begins. In order to more clearly determine the locations of strongest gradients, which correspond to the centers of currents, we elect fields of horizontal gradients instead.

In the following figures, the sea surface temperatures presented were recorded at engine room intakes, which were actually about $3 \mathrm{~m}$ below the sea surface. Derived from CTD data are horizontal gradients of temperature and salinity, together with geostrophic velocities and transports computed by using reference depths given by Stramma [1984]. Those depths were obtained by using mean density profiles combined with information on the advection of water masses from oxygen and salinity extrema and a mass conservation scheme developed by Fiadeiro and Veronis [1982]. The resulting zero reference plane lies at a depth of $1500 \mathrm{~m}$ in the tropical eastern North Atlantic and at $1200 \mathrm{~m}$ in the subtropics [Stramma, 1984, Figure 6]. The total error for the 0- to 1000-m transport, caused by uncertainty in the reference level and data noise, was estimated to be $15 \%$. The gyre circulation is limited to the upper ocean, with most of its transport being within $500 \mathrm{~m}$ of the surface. Our figures show transport fields for the layer 0 to $800 \mathrm{~m}$, thus representing nearly all the gyre transport. Below 800-m depth the flow field is weak [Stramma, 1984] and is complicated by the Mediterranean Water outflow, and it is not discussed here.

The jointed section M60 (Figure 1), which crossed the Azores Current (AzC) in April 1982, is presented in Figure 3. The temperature and salinity gradients are computed with actual distances and are then projected onto $33^{\circ} \mathrm{W}$. Therefore the dots indicating station locations are closer together north of $35^{\circ} \mathrm{N}$ than they are south of that latitude, whereas the actual distances were about the same over the entire section. If the original temperature and salinity fields were projected onto $33^{\circ} \mathrm{W}$ prior to the computations, the resulting gradients north of $35^{\circ} \mathrm{N}$ would be more intense, but the spatial patterns would be unchanged.
The Azores Current had a transport of about $10 \mathrm{~Sv}(1 \mathrm{~Sv}=$ $10^{6} \mathrm{~m}^{3} / \mathrm{s}$ ) to the east between the surface and $800-\mathrm{m}$ depth, with surface velocities exceeding $10 \mathrm{~cm} / \mathrm{s}$ between $34^{\circ}$ and $35^{\circ} \mathrm{N}$. The true maximum values of velocity within the current were likely larger than they appear here because of the relatively large station spacing. The largest velocities were at the surface, whereas the most intense northward temperature and salinity gradients were between 100 - and $600-\mathrm{m}$ depth. In the upper $100 \mathrm{~m}$ the gradients weakened and shifted toward the north, with the strongest surface gradients for both temperature and salinity being between $35^{\circ}$ and $36^{\circ} \mathrm{N}$. Also, the sharpest changes in surface temperature were north of $35^{\circ} \mathrm{N}$ (Figure $3 a$ ). The surface temperature changed by more than $1^{\circ} \mathrm{C}$, which should make this temperature front visible to satellite IR observations. Surface temperature measurements both by satellites and ships would show the surface front, but to the north of where an XBT section would show the Azores Current.

A minimum in surface temperature was recorded at the surface front (Figure $3 a$ ). Such temperature signatures have been noted in records from numerous crossings of the Antarctic Polar Front and the Subantarctic Front [Lutjeharms and Valentine, 1984] and in the Sargasso Sea [Katz, 1969]. However, no physical explanations are available. Also, at the Antarctic Polar Front, Lutjeharms and Valentine observed that in about $75 \%$ of the cases the subsurface expressions were to the north of those at the surface.

With regard to the section made in November 1985 at $26^{\circ} 30^{\prime} \mathrm{W}$ (Figure 4), the Azores Current had a transport of about $8 \mathrm{~Sv}$ to the east between the surface and $800 \mathrm{~m}$ but was spread across a broader extent than at $33^{\circ} \mathrm{W}$. The largest near-surface velocities, about $9 \mathrm{~cm} / \mathrm{s}$, were just south of $35^{\circ} \mathrm{N}$, while north of $36^{\circ} \mathrm{N}$ there was a small intense westward current band that had a velocity maximum of about $7 \mathrm{~cm} / \mathrm{s}$ near $500-\mathrm{m}$ depth. No large northward shift is observed in the surface expression such as in Figure 3. The temperature gradient again had a subsurface maximum but was directly beneath the largest surface gradient, which is where the maximum salinity gradient also occurred.

The surface temperature record in Figure 4 is not continuous owing to a break of $\mathbf{3 . 5}$ days for mooring work. It is likely that the sharp change in surface temperature that occurred then, about $1^{\circ} \mathrm{C}$, was an expression of the Azores Current. But both the ship intake record and the vertical section of temperature gradient show that the largest changes were near $37^{\circ} \mathrm{N}$, north of the narrow westward flow. As in the case of Figure 3, several XBT sections (not shown) made in this area clearly show a temperature front related to the Azores Current. Although in this section there is more than one region having strong thermal gradients, the one related to the Azores Current could probably be identified in a satellite IR image on the basis of spatial patterns.

The shift of the surface manifestation of the front in Figure 3 likely cannot be explained by Ekman transport. Weather observations by $\mathrm{R} / \mathrm{V}$ Meteor during the period of crossing the Azores Current showed winds with stable strength from the northwest, while those by R/V Poseidon showed northerly winds north of $34^{\circ} 10^{\prime} \mathrm{N}$, changing to easterlies south of $34^{\circ} \mathrm{N}$ and south of the Azores Current. These winds are inconsistent with what would be required to cause the observed frontal tilt. Also, monthly means of Ekman transports in the region are not consistent with the frontal shift. They are directed to the southeast in April and to the west in November [Isemer and Hasse, 1987]. 

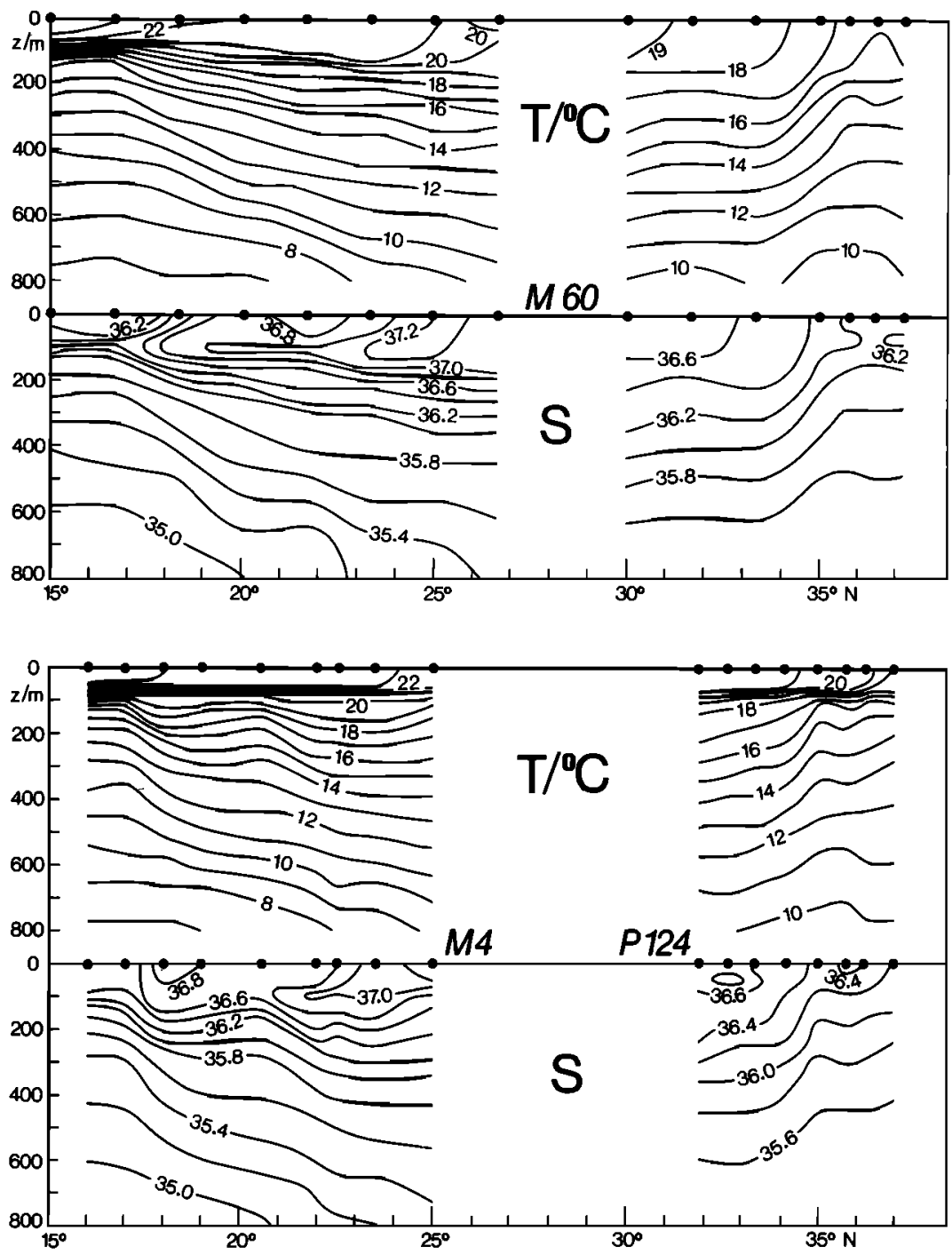

Fig. 2. Vertical sections of temperature and salinity for (top) spring and (bottom) fall projected onto longitude. CTD stations are denoted by dots; ship identification is as in Figure 1.

An oceanic front in the Sargasso Sea was studied by Katz [1969], who showed that frontal curvatures and slopes were in close agreement with geostrophic conditions, i.e., the slope was a geostrophic result of the relative motion of two adjacent water masses. Similar observations of frontal tilt in the Sargasso Sea were made by Voorhis and Hersey [1964]. A twodimensional primitive equation model was used by R. Onken, J. Fischer, and J. D. Woods (personal communication, 1988) to simulate the response of temperature distributions to the dynamics of mesoscale frontogenesis. They found that the isopycnic temperature gradient exhibits a local maximum on the cyclonically sheared side of the frontal jet and that the thermal front is tilted toward the cyclonic side when approaching the top of the thermocline. The cross-jet asymmetry is due to the divergence of the cross-jet ageostrophic mass flux, whereas the tilt is a product of the cross-front advection of the isopycnic temperature gradient. A more definitive explanation for the shift awaits further investigation.

Observations from the crossing of the NEC at $27^{\circ} \mathrm{W}$ in March 1982 are presented in Figure 5. The NEC was centered at $21^{\circ} \mathrm{N}$, having a transport of about $9 \mathrm{~Sv}$ to the west between the surface and $800 \mathrm{~m}$. The largest velocities were in the upper $400 \mathrm{~m}$, with the maximum being at the sea surface. In contrast to the Azores Current, there were no strong horizontal salinity or temperature gradients related to the NEC. In fact, stronger gradients in temperature and salinity were about $2^{\circ}$ to the south, just north of $19^{\circ} \mathrm{N}$ between 200 - and $500-\mathrm{m}$ depth. These gradients in temperature and salinity correspond to the water mass boundary between the North Atlantic Central Water and the South Atlantic Central Water (SACW) which we will call the Cape Verde Front. Strong currents are not associated with the Cape Verde Front because the salinity and temperature gradients are density compensating. Another area of strong gradients occurred between $17^{\circ}$ and $18^{\circ} \mathrm{N}$ between $100-$ and $200-\mathrm{m}$ depth. This was associated with geostrophic shears and was likely due to a small-scale intrusion of water from the south that was sampled at $16^{\circ} 40^{\prime} \mathrm{N}$. The temperature and salinity values (not shown) at that station were about the same as those observed near $13^{\circ} \mathrm{N}$ during the same cruise. Near $23^{\circ} \mathrm{N}$ and between 50 and $150 \mathrm{~m}$ within the center of the gyre, the subtropical subsurface salinity maximum occurs [Bauer and Siedler, 1988].

The NEC was located within the NACW, with the Cape Verde Front being farther south. This could be a reason for the Cape Verde Front existing across the entire tropical Atlantic as opposed to losing its identity through mixing processes 


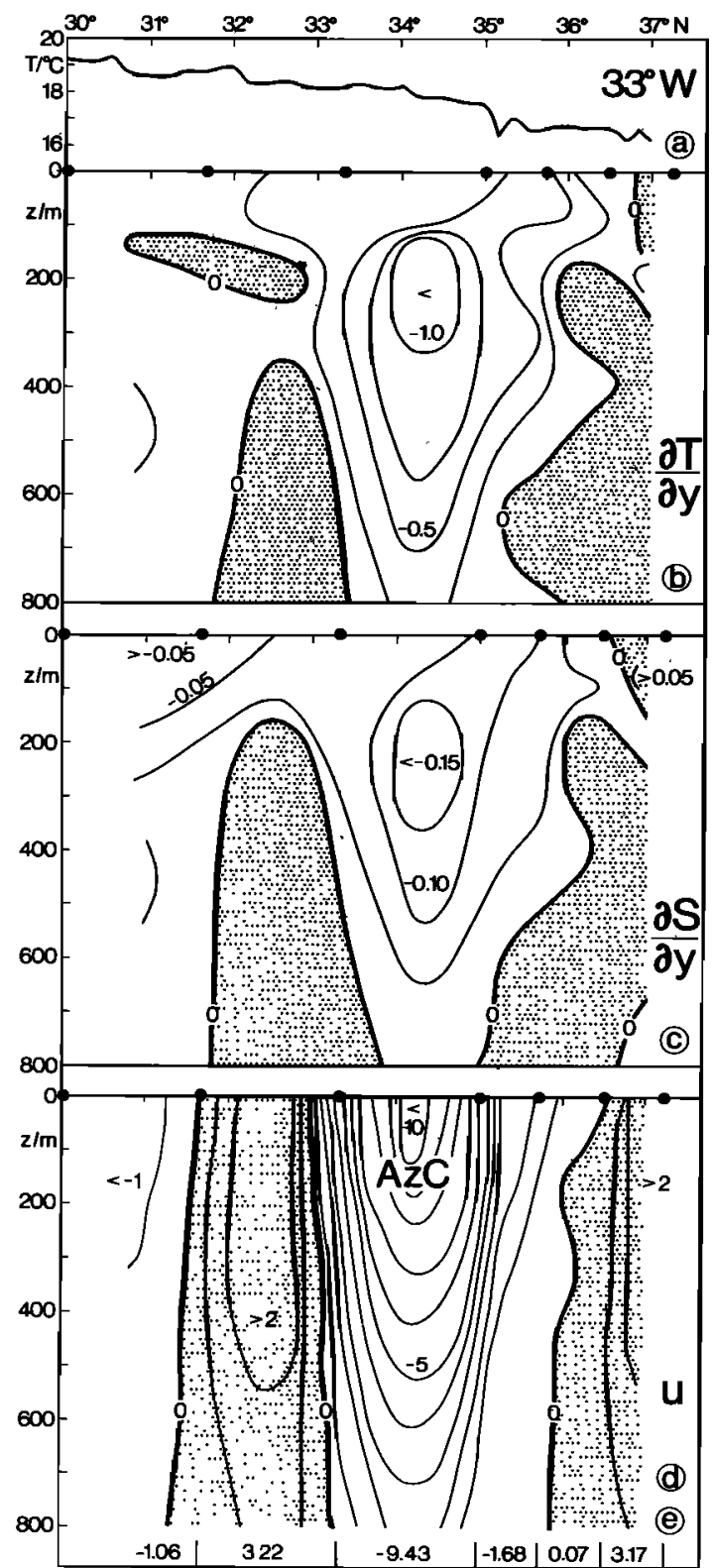

Fig. 3. Vertical sections across the Azores Current (AzC) from Meteor cruise 60 in April 1982 projected onto $33^{\circ} \mathrm{W}:(a)$ surface temperature measured at ship's intake, in degrees Celsius; (b) CTDderived northward temperature gradient, in degrees Celsius per 100 $\mathrm{km}$; (c) northward salinity gradient $(1 / 100 \mathrm{~km}) ;(d)$ geostrophic velocily in centumeters per second (positive to the west); and (e) geostrophic transport from 0- to 800-m depth in sverdrups $\left(1 \mathrm{~Sv}=10^{6} \mathrm{~m}^{3} / \mathrm{s}\right)$ with transport positive to the west. The reference layer is defined in text. CTD stations are denoted by dots.

[Tomczak, 1984]. In a zonal section along $22^{\circ} \mathrm{N}$ near the African coast, Barton [1987] showed the southward flowing current, which is part of the source of the NEC, to be west of the front within the warm and saline NACW, although the separation amounted to only a few kilometers. Barton also observed the strong thermohaline front to have little density signature and no enhanced geostrophic shears. He estimated the frontal width as $10 \mathrm{~km}$, with associated temperature and salinity contrasts of up to $3^{\circ} \mathrm{C}$ and 1 practical salinity unit ( $1 \%$ by weight). In Figure $5 a$ the ship surface temperature shows only a small step in temperature just north of the NEC, which is too small to be clearly measured by satellite IR data.

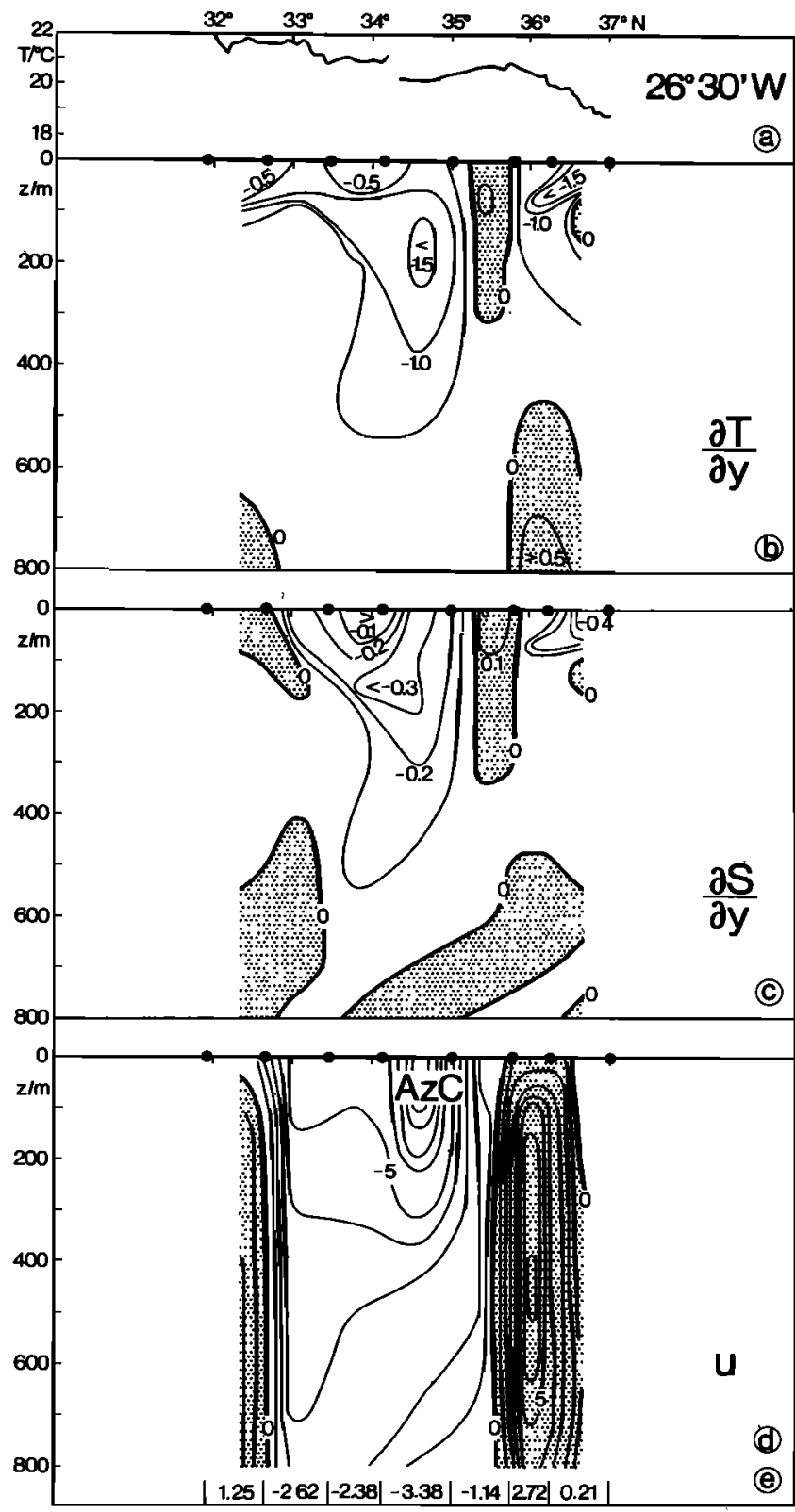

Fig. 4. As in Figure 3 but at $26^{\circ} 30^{\prime} \mathrm{W}$ by $\mathrm{R} / \mathrm{V}$ Poseidon in midNovember 1985.

Legeckis [1978] surveyed very high resolution radiometer measurements and pointed out that within the band of $25^{\circ} \mathrm{N}$ to $25^{\circ} \mathrm{S}$ the sea surface is nearly isothermal. Although instrumentation and computational algorithms have been improved since that time, it still seems that the NEC is unobservable by satellite IR imagery. However, it might be observable in the future with satellite altimetry.

The horizontal gradients of temperature and salinity at the NEC (Figure $5 b$ ) correspond to anomalous distributions in the upper $100 \mathrm{~m}$. While NACW is normally warmer and saltier than SACW, the surface layer here contained warmer, saltier water in the south. This reversal highlights the difficulty in using surface temperature as an indicator of the NEC. However, the salinity gradient shows no such anomalous reversal above the Cape Verde Front, and is measurable at the surface.

Indications that the NEC carries only NACW can also be found in the distribution of tritium along a section at about $27^{\circ} \mathrm{W}$ made in March 1981 [Thiele et al., 1986, Figure 4]. On 


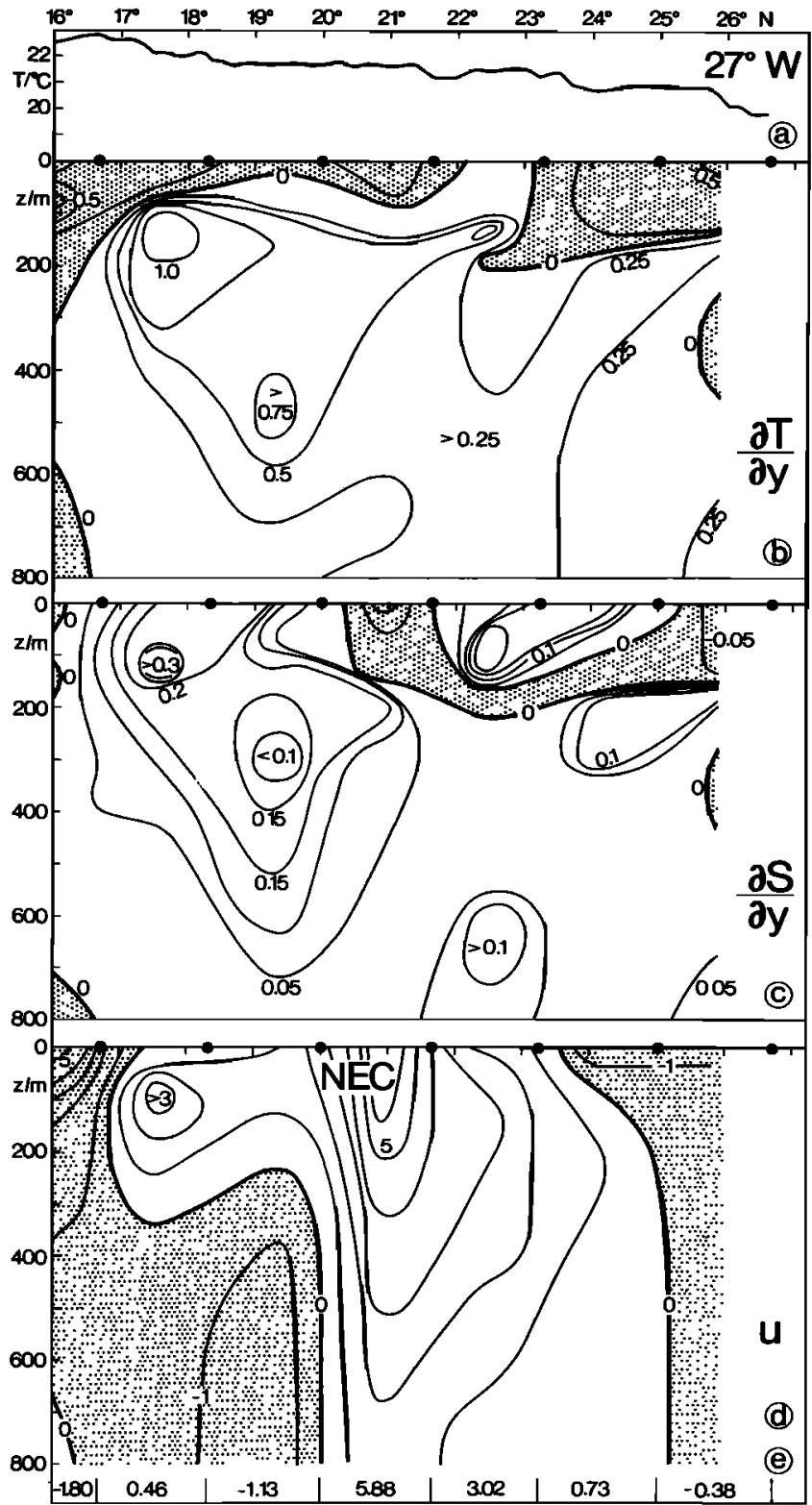

Fig. 5. As in Figure 3 but across the North Equatorial Current (NEC) at $27^{\circ} \mathrm{W}$ by $\mathrm{R} / \mathrm{V}$ Meteor in March 1982 . Here negative values are shaded.

the $\sigma_{t}$ surfaces 25.5 and 26.8 , tritium values were lowest south of $10^{\circ} \mathrm{N}$ then increased within the Cape Verde Front, reaching a maximum at $20^{\circ} \mathrm{N}$. After decreasing slightly toward $30^{\circ} \mathrm{N}$, they once again increased, finally attaining values north of $35^{\circ} \mathrm{N}$ that were larger than those at $20^{\circ} \mathrm{N}$. The tritium maxima at $20^{\circ} \mathrm{N}$ on the two surfaces were higher than those at the sea surface at the same location. Therefore the maxima were due to the NEC carrying water from regions north of $35^{\circ} \mathrm{N}$ within the subtropical gyre to the south, then to the west at $20^{\circ} \mathrm{N}$. The subsurface maxima of tritium levels show that this water must originate from the North Atlantic and that almost no mixing with the SACW takes place, as the SACW has very low tritium concentrations.

The meridional section across the NEC at $27^{\circ} \mathrm{W}$ in November 1986 from cruise 4 of the new Meteor is presented in Figure 6. As in the March section, there appears to be no clear surface temperature signal related to the NEC. The strongest

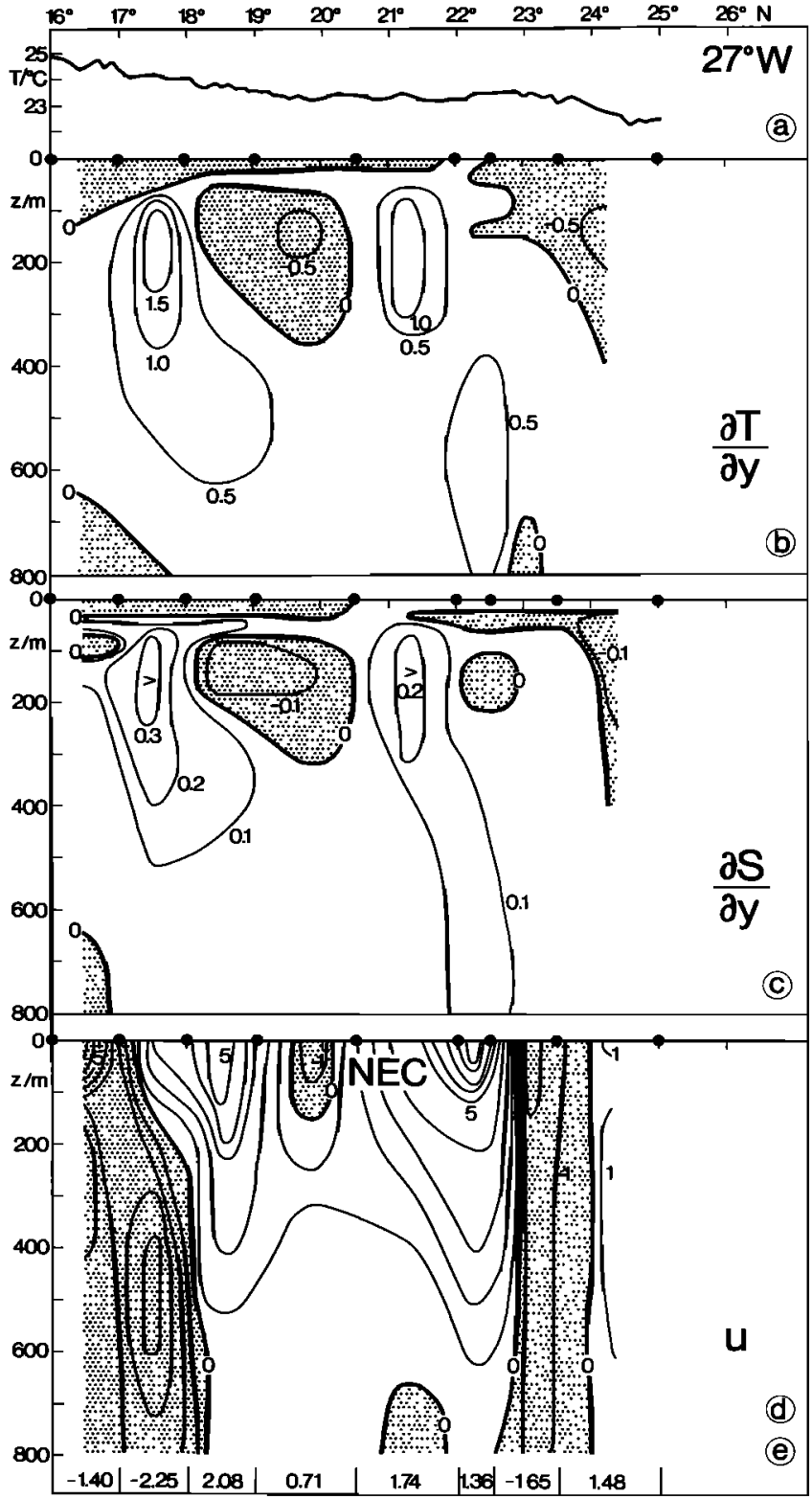

Fig. 6. As in Figure 3 but across the NEC at $27^{\circ} \mathrm{W}$ by $\mathrm{R} / \mathrm{V}$ Meteor in November 1986. Here negative values are shaded.

velocity was found just north of $22^{\circ} \mathrm{N}$, or about $1^{\circ}$ north of where it was in March 1982. This is due to the northward shift of the NEC in fall [Richardson and Walsh, 1986]. Another strong current band is found between $18^{\circ}$ and $19^{\circ} \mathrm{N}$, and as with the band near $22^{\circ} \mathrm{N}$, the strongest gradients of temperature and salinity are found at depth about $1^{\circ}$ to the south. No significant temperature or salinity gradients are seen above 50-m depth. The total westward transport of the NEC of about $6 \mathrm{~Sv}$ is surprisingly small. This is in contrast to computations from all historic profiles in the eastern North Atlantic that gave typical transports of 8 to $10 \mathrm{~Sv}$ [Stramma, 1984].

\section{CONCLUSIONS}

Spring and fall observations in the regions containing the two zonal currents of the subtropical gyre in the eastern North Atlantic, the Azores Current and the North Equatorial Current, show that they possess dissimilar structures. The Azores Current is related to strong horizontal thermohaline 
gradients that are not density compensating, resulting in strong geostrophic shears. These horizontal gradients can tilt upward toward the north near the surface. To find and observe the Azores Current with simple oceanographic methods, the use of XBT sections seems to be appropriate. Additionally, XBT sections can be used to compute geostrophic profiles with the aid of historical temperature-salinity $(T-S)$ curves averaged on $3^{\circ} \times 3^{\circ}$ squares [Siedler and Stramma, 1983]. That method is used here to recalculate transports across the two M60 sections. Salinities used are the weighted averages from the $3^{\circ} \times 3^{\circ}$ squares north and south of the ship positions. Here the 0 - to $800-\mathrm{m}$ transport between $33^{\circ} 20^{\prime} \mathrm{N}$ and $36^{\circ} 30^{\prime} \mathrm{N}$ is $12.5 \mathrm{~Sv}$ to the east, as compared to $11.0 \mathrm{~Sv}$ from actual salinities. The strongest flow is observed at the correct location between $33^{\circ} 20^{\prime} \mathrm{N}$ and $35^{\circ} \mathrm{N}$ with $11.0 \mathrm{~Sv}$. It appears that XBT profiles combined with mean T-S curves can provide good estimates of geostrophic shear at the Azores Current. Käse et al. [1985] showed that such computations may also compare well with geoelectrokinetograph (GEK) and expendable current profiler measurements. Surface temperature and salinity measured at ship intakes might also be used as indicators of this current, but such a surface manifestation might be shifted to the north of the subsurface front. The shift is apparently not related to wind-induced Ekman transport, and it awaits further investigation. IR measurements by satellite of the sea surface might also serve as a tool to observe the thermal front related to the Azores Current. But there is a disadvantage in that substantial cloud cover south of the Azores is frequent during much of the year, particularly in winter. This is compounded by observations showing that in midsummer the front is capped by a strong seasonal thermocline [Gould, 1985], implying that the sharpest surface thermal gradient will occur mainly in the winter months. According to Legeckis [1978], at latitudes higher than $35^{\circ}$, frontal observations are independent of seasons, and between $25^{\circ}$ and $35^{\circ}$ they are restricted to the autumn, winter, and spring months.

The NEC has weaker horizontal thermohaline gradients than does the water mass boundary between the central waters just south of the current, which are density compensating. XBT sections will clearly show the water mass boundary to the south but not the NEC. Likewise, surface observations of temperature or salinity can probably detect the southern water mass boundary but not the NEC. As was done for the Azores Current, the NEC transport of the M60 section is recalculated with the aid of mean T-S profiles. Between $23^{\circ} 20^{\prime} \mathrm{N}$ and $20^{\circ} \mathrm{N}$ the $0-$ to $800 \mathrm{~m}$ transport is estimated as $2.7 \mathrm{~Sv}$ to the west, which compares poorly with the $8.9 \mathrm{~Sv}$ from actual salinities. We conclude that the NEC can not be adequately sampled without obtaining vertical profiles of both temperature and salinity.

While our observations come from only one spring and one fall section for each current, and variations in time are possible, we feel that the structures of these currents as observed here are quite similar to the mean structures, even though there are seasonal shifts in their positions [Stramma and Sied$l e r, 1988]$. The mean transport fields from historical data are spread over large areas owing to smoothing, so a comparison between those fields and the sections presented here would have little meaning. More sections, with smaller station spacing, are needed to better describe the Azores and North Equatorial currents and to provide statistical information. However, the sections presented here show large-scale features of these rarely investigated currents and also show in which regions simple observation methods can be used.
Acknowledgments. We thank R. G. Peterson for reviewing the manuscript. We would like to acknowledge the assistance of the staff of the Marine Physics Group at the Institut für Meereskunde, Kiel, and the help of the crews of $\mathrm{R} / \mathrm{V}$ Meteor and $\mathrm{R} / \mathrm{V}$ Poseidon. This work was supported by the Deutsche Forschungsgemeinschaft Bonn, Federal Republic of Germany, SFB 133, and under federal grant BMFT 07 KF 2128(VH12a).

\section{REFERENCES}

Barton, E. D., Meanders, eddies and intrusions in the thermohaline front off northwest Africa, Oceanol. Acta, 10, 267-283, 1987.

Bauer, E., and G. Siedler, The relative contributions of advection and isopycnal and diapycnal mixing below the subtropical salinity maximum, Deep Sea Res., 35, 811-838, 1988.

Cornillon, P., The effect of the New England seamounts on Gulf Stream meandering as observed from satellite IR imagery, $J$. Phys. Oceanogr., 16, 386-389, 1986.

Cornillon, P., and D. R. Watts, Satellite thermal infrared and inverted echo sounder determinations of the Gulf Stream northern edge, $J$. Atmos. Oceanic Technol., 4, 712-723, 1987.

Fasham, M. J. R., T. Platt, B. Irwin, and K. Jones, Factors affecting the spatial pattern of the deep chlorophyll maximum in the region of the Azores Front, Prog. Oceanogr., 14, 129-165, 1985.

Fiadeiro, M. E., and G. Veronis, On the determination of absolute velocities in the ocean, J. Mar. Res., 40, suppl., 159-182, 1982.

Fiedler, P. C., Surface manifestations of subsurface thermal structure in the California Current, J. Geophys. Res., 93, 4975-4983, 1988.

Gould, W. J., Physical oceanography of the Azores Front, Prog. Oceanogr., 14, 167-190, 1985.

Isemer, H.-J., and L. Hasse, The Bunker Climate Atlas of the North Atlantic Ocean, vol. 2, Air-Sea Interactions, 252 pp., SpringerVerlag, New York, 1987

Käse, R. H., and G. Siedler, Meandering of the subtropical front south-east of the Azores, Nature, 300, 245-246, 1982.

Käse, R. H., W. Zenk, T. B. Sanford, and W. Hiller, Currents, fronts and eddy fluxes in the Canary Basin, Prog. Oceanogr., 14, 231-257, 1985.

Käse, R. H., J. F. Price, P. Richardson, and W. Zenk, A quasisynoptic survey of the thermocline crrculation and water mass distribution within the Canary Basin, J. Geophys. Res., 91, 9739-9748, 1986.

Katz, E. J., Further study of a front in the Sargasso Sea, Tellus, 21, 259-269, 1969.

Legeckis, R., A survey of worldwide sea surface temperature fronts detected by environmental satellites, $J$. Geophys. Res., 83, 4501$5422,1978$.

Lutjeharms, J. R. E., and H. R. Valentine, Southern ocean thermal fronts of south of Africa, Deep Sea Res., 3I, 1461-1475, 1984.

Rıchardson, P. L., and D. Walsh, Mapping climatological seasonal variations of surface currents in the tropical Atlantic using ship drifts, J. Geophys. Res., 91, 10,537-10,550, 1986.

Siedler, G., and L. Stramma, The applicability of the $T / S$ method to geopotential anomaly computations in the northeast Atlantic, Oceanol. Acta, 6, 167-172, 1983.

Siedler, G., W. Zenk, and W. J. Emery, Strong current events related to a subtropical front in the northeast Atlantic, J. Phys. Oceanogr., I5, 885-897, 1985.

Stramma, L., Geostrophic transport in the warm water sphere of the eastern subtropical North Atlantic, J. Mar. Res., 42, 537-558, 1984.

Stramma, L., and G. Siedler, Seasonal changes in the North Atlantic subtropical gyre, J. Geophys. Res., 93, 8111-8118, 1988.

Thiele, G., W. Roether, P. Schlosser, R. Kuntz, G. Siedler, and L. Stramma, Baroclınic flow and transient tracer fields in the CanaryCape Verde Basin, J. Phys. Oceanogr., 16, 814-826, 1986.

Tomczak, M., Ausbreitung und Vermischung der Zentralwassermassen in den Tropengebieten der Ozeane, 1, Atlantischer Ozean, Oceanol. Acta, 7, 145-158, 1984.

Voorhis, A. D., and J. B. Hersey, Ocean thermal fronts in the Sargasso Sea, J. Geophys. Res., 69, 3809-3814, 1964.

T. J. Müller and L. Stramma, Institut für Meereskunde an der Universität Kiel, Düsternbrooker Weg 20, 2300 Kiel, Federal Republic of Germany.
(Received September 16, 1988; accepted October 14, 1988.) 